\title{
Membangun Perencanaan dan Kinerja Tim: Analisis Pengaruh Efikasi Kolektif dan Iklim Kecerdasan Emosional
}

\section{Building Planning and Team Performance: Analysis of Collective Efficacy and Emotional Intelligence Climate Dewiana Novitasari ${ }^{1}{ }^{*}$, Dhaniel Hutagalung1, Nelson Silitonga ${ }^{1}$, Muhammad Johan', Masduki Asbari ${ }^{2}$}

\author{
1)Sekolah Tinggi Ilmu Ekonomi Insan Pembangunan, Tangerang, Indonesia \\ 2)STMIK Insan Pembangunan, Tangerang, Indonesia
}

*Corresponding Email: jemhrd@gmail.com

\begin{abstract}
Abstrak
Penelitian ini mendalilkan karakteristik tim dan faktor lingkungan sebagai pendorong utama team performance. Dalam model yang diusulkan dari studi ini, kinerja tim dipengaruhi secara positif dan signifikan oleh efikasi kolektif dan iklim kecerdasan emosional. Demikian juga, perencanaan tim kerja berpengaruh secara positif dan signifikan terhadap kinerja tim. Data dikumpulkan dari 103 karyawan penjualan dari salah satu industri manufaktur di Indonesia yang diambil secara random sampling. Data dianalisis menggunakan metode SEM dengan software SmartPLS 3.0, Hasil penelitian ini menunjukkan bahwa efikasi kolektif dan iklim kecerdasan emosional berpengaruh positif dan signifikan terhadap perencanaan tim kerja dan kinerja tim. Demikian juga perencanaan tim kerja berpengaruh secara positif dan signifikan terhadap kinerja tim. Selain itu, pengujian empiris penelitian ini, dengan menyelidiki anggota tim penjualan yang bekerja di industri manufaktur Indonesia, melengkapi penerapan teori kognitif sosial dalam memahami kinerja tim. Terakhir, implikasi manajerial tentang kinerja tim dan open problem di masa depan dibahas pada akhir laporan penelitian.

Kata Kunci: Efikasi Kolektif, Iklim Kecerdasan Emosional, Kinerja Tim, Perencanaan Tim Kerja.

Abstract

This study postulates team characteristics and environmental factors as the main drivers of team performance. In the proposed model of this study, team performance is positively and significantly affected by collective efficacy and emotional intelligence climate. Likewise, team planning has a positive and significant effect on team performance. Data werecollected from 103 of sales/marketing employees of a manufacturing industry in Indonesia by random sampling. Data were analyzed using SEM method with SmartPLS 3.0 software. The results of this study indicated that collective efficacy and emotional intelligence climate have a positive and significant effect on team planning and team performance. Likewise, team planning has a positive and significant effect on team performance. Moreover, the empirical test of this study, by investigating sales/marketing employees working in the Indonesian manufacturing industry, complements the application of social cognitive theory in understanding team performance. Finally, the managerial implications of team performance and future open problems are discussed at the end of the research report.
\end{abstract}

Keywords: Collective Efficacy, Emotional Intelligence Climate, Team Performance, Team Planning.

How to Cite: Novitasari, D., Hutagalung, D., Silitonga, N., Johan, M. \& Asbari, M. (2021). Membangun Perencanaan dan Kinerja Tim: Analisis Pengaruh Efikasi Kolektif dan Iklim Kecerdasan Emosional. JKBM (Jurnal Konsep Bisnis dan Manajemen). 7 (2): 191-205 


\section{PENDAHULUAN}

Sebuah tim dalam organisasi mewakili sekelompok individu pegawai yang menganggap diri mereka sebagai kumpulan sosial yang dapat diidentifikasi dalam suatu organisasi (Asbari \& Novitasari, 2020; Asbari \& Prasetya, 2021; Purwanto et al., 2019). Kerjasama dalam tim telah mendapat banyak perhatian dari psikolog sosial dan organisasi, karena hal itu membawa manfaat penting bagi karyawan dan organisasinya, seperti menyediakan cara yang efektif untuk mengumpulkan ide-ide kreatif, meningkatkan komunikasi antarpribadi, meningkatkan semangat tim, memfasilitasi perencanaan tim, dan meningkatkan kinerja tim (Dalimunthe, 2018; Harmen, 2018). Literatur sebelumnya mengungkapkan bahwa kinerja tim tetap menjadi masalah abadi dan penting bagi banyak praktisi dan akademisi (Asbari, Hidayat, et al., 2021; Gazali et al., 2020; Novitasari et al., 2020, 2020; Novitasari \& Asbari, 2020a, 2020b; Singgih et al., 2020). Sebuah teori kunci yang telah menghasilkan minat yang cukup besar sebagai alasan untuk menjelaskan kinerja tim ada-lah teori kognitif sosial/social cognitive theory (SCT) dari Bandura (1991). SCT adalah teori yang memberikan wawasan tentang perilaku masyarakat dan kinerja mereka. Menurut SCT, karyawan memiliki sistem organisasi yang memungkinkan mereka untuk melakukan tindakan pengendalian atas pikiran, perasaan, dan tindakan mereka (OtayeEbede et al., 2019). Sistem ini menyediakan mekanisme referensi dan seperangkat sub-fungsi untuk memahami, mengatur, dan mengevaluasi perilaku, yang dihasilkan dari interaksi antara sistem dan sumber pengaruh lingkungan. SCT telah banyak digunakan dalam berbagai disiplin ilmu dan pengaturan praktis dan telah menerima dukungan empiris dari penelitian sebelumnya tentang masalah tim yang terus berkembang. Misalnya, efikasi kolektif, komponen penting dari SCT, telah ditemukan terkait dengan masalah anggota tim seperti kesulitan tujuan yang ditetapkan tim, kepuasan kerja, kesejahteraan psikologis, perilaku kewarganegaraan organisasi/organizational citizenship behavior (OCB) (Joe \& Lin, 2008) dan kinerja tim (Park et al., 2017).

Hasil penelitian sebelumnya menunjukkan bahwa hubungan antara efikasi kolektif dan kinerja tim dimediasi oleh berbagai variabel mediasi seperti pemberdayaan kepemimpinan dan tujuan tim (Chen et al., 2010). Memperluas temuan sebelumnya, studi ini lebih jauh mengeksplorasi efikasi kolektif yang mempengaruhi kinerja tim berdasarkan SCT. Faktor mediasi penting untuk hubungan kinerja tim-efikasi kolektif adalah perencanaan tim yang mewakili taktik pengaturan diri tim yang diadopsi oleh anggota tim untuk mengejar tujuan tim (Mehta et al., 2009).

Perencanaan tim kerja didefinisikan sebagai aktivitas bekerja sama yang mengharuskan tim untuk menyusun tindakan yang dapat digunakan untuk mencapai tujuan yang telah dipilih (Mehta et al., 2009). Penelitian sebelumnya telah menyarankan bahwa perencanaan tim kerja (yaitu, swaregulasi) secara langsung mempengaruhi kinerja (Mehta et al., 2009), dan tim dengan tingkat efikasi yang berbeda dapat merespons secara berbeda dengan berbagai taktik pengaturan diri untuk memandu aktivitas kerja sama dari waktu ke waktu. Perencanaan tim kerja telah diakui sebagai mediator meta-kognitif penting untuk peningkatan 
kinerja tim. DeShon \& Gillespie (2005) menunjukkan "rencana aksi" sebagai cara yang efisien untuk mencapai tujuan organisasi dan pembuktian kinerja, sehingga menyarankan peran mediasi potensial dari perencanaan tim. Studi ini menyarankan bahwa kerja tim dengan komunikasi yang efisien dapat menghindari kurangnya perencanaan tim kerja dan pada akhirnya mencapai performa tim yang prima.

Penelitian ini menilai bagaimana perencanaan tim kerja, sebagai taktik pengaturan diri utama, memediasi hubungan antara efikasi kolektif, iklim kecerdasan emosional dan kinerja tim. Perencanaan tim kerja telah diakui sebagai pendekatan regulasi penting dan proses berbasis tim untuk meningkatkan kinerja tim. Perencanaan adalah keterampilan meta-kognitif penting yang berpengaruh terhadap kinerja organisasi. Tim menggunakan perencanaan sebagai taktik untuk mengoordinasikan berbagai aktivitas rumit, sehingga meningkatkan kinerja mereka (Asbari, Purba, et al., 2021a; Novitasari \& Asbari, 2021). Terlepas dari bukti bahwa perencanaan bersama adalah taktik pengaturan diri yang vital, sedikit perhatian telah diberikan untuk mengevaluasi peran perantara dalam pembentukan kinerja bersama berdasarkan SCT, yang dibahas dalam penelitian ini.

Penelitian ini berbeda dengan penelitian sebelumnya dari sisi bahwa studi ini mengevaluasi perencanaan tim yang belum teruji sebagai mediator pembentukan kinerja tim berbasis SCT dengan antseden collective efficacy dan iklim kecerdasan emosional. Model ini masih relevan untuk diteliti dan diuji, lebih-lebih di industri manufaktur. Studi ini juga mencoba melengkapi literatur sebelumnya dengan mensurvei hubungan antara efikasi kolektif sebagai faktor individual dan iklim kecerdasan emosional sebagai faktor lingkungan dengan kinerja tim, yang dimediasi oleh perencanaan tim.

Untuk membangun model kinerja tim, studi ini mengambil dari postulat kunci dan temuan dalam social cognitive theory (SCT). SCT adalah teori yang diterima secara luas yang memberikan alasan kritis mendalam untuk membenarkan bagaimana tim melakukan perilaku tertentu dan mencapai hasil selanjutnya. SCT menjelaskan fungsi tim dalam hal penyebab timbal balik di mana karakteristik tim, faktor lingkungan (yang mengelilingi tim) dan perilakunya beroperasi sebagai penentu interaksi dari perilaku dan hasil tim. Berdasarkan SCT, studi ini mengusulkan model penelitian di mana perencanaan tim kerja dan kinerja tim (yaitu, perilaku dan hasil) secara langsung dipengaruhi oleh karakteristik tim (yaitu, efikasi kolektif) dan faktor lingkungan (yaitu, iklim kecerdasan emosional). Sementara itu, kinerja tim juga dipengaruhi oleh perencanaan tim kerja. Asumsi dalam model ini dapat dibenarkan tidak hanya dari perspektif teoritis SCT, tetapi juga dari sudut pandang kerjasama praktis. Sebagai contoh, banyak literatur sebelumnya telah menunjukkan bahwa hasil kerjasama yang baik membutuhkan tingkat tertentu dari dalam (misalnya, self-efficacy) dan dari luar (misalnya, organizational climate).

Perencanaan tim sebagai taktik pengaturan diri adalah proses kognitif dan perilaku yang memandu aktivitas tim yang diarahkan pada tu-juan dari waktu ke waktu (Choi et al., 2017). Untuk berhasil mengejar tujuan tim, penting untuk memiliki efikasi kolektif yang kuat sehingga perencanaan 
tim dapat dirancang secara efektif dan efisien oleh tim. Memang. Perencanaan tim kerja adalah komponen penting dari meta-kognisi, yang mengacu pada kesadaran dan kontrol individu atas kognisi mereka (Maxwell et al., 2019). Tim dengan efektivitas yang lebih tinggi menunjukkan keterampilan meta-kognitif yang lebih baik karena mereka memiliki kepercayaan diri untuk merencanakan tugas mereka, mengantisipasi masalah sebelumnya, dan kecepatan dalam menyesuaikannya, menunjukkan hubungan positif antara efikasi kolektif dan perencanaan tim. Sebaliknya, tim dengan efikasi rendah sering kali ragu-ragu untuk merencanakan aktivitas penting dan melakukannya tepat waktu, akibatnya perencanaan tim yang lemah. Berdasarkan dasar pemikiran dan justifikasi di atas, maka dikembangkan hipotesis sebagai berikut.

H1. Efikasi kolektif berpengaruh positif dan signifikan terhadap perencanaan tim kerja.

Efikasi kolektif berasal dari individu anggota tim, dan melalui proses pengalaman tugas tim yang saling bergantung dan interaksi sosial yang aktif, self-efficacy anggota bersama-sama menyatu menjadi variabel tingkat tim. Efikasi kolektif adalah kepercayaan diri (atau keyakinan) tim mengenai peluangnya untuk berhasil menyelesaikan misi tim tertentu (Kreitner \& Kinicki, 2014). Efikasi kolektif memengaruhi apa yang coba dilakukan oleh anggota tim, berapa banyak upaya yang mereka lakukan untuk mengejar tujuan tim, dan ketekunan mereka ketika upaya tim yang gagal mencapai target tim (Bandura, 1977). Studi sebelumnya telah menunjukkan hubungan yang kuat antara efikasi kolektif dan kinerja tim (Ma et al., 2017; Park et al., 2017; Yaakobi \& Weisberg,
2020). Tim dengan efikasi kolektif yang tinggi diperkirakan akan berhasil mencapai kinerja yang baik dalam berbagai situasi pencapaian. Akibatnya, efikasi kolektif yang kuat memfasilitasi peningkatan kinerja tim mereka setelah kegagalan, sementara efikasi kolektif yang lemah menyebabkan kinerja tim menurun (Bandura et al., 1994). Dengan demikian hipotesis diturunkan seperti di bawah ini.

H2. Efikasi kolektif berpengaruh positif dan signifikan terhadap kinerja tim.

Kecerdasan emosional diyakini dapat meningkatkan rasa tanggung jawab, pemecahan masalah, pengujian realitas, toleransi stres, kontrol impuls, dan kebahagiaan individu. Kondisi ini menumbuhkan suasana dan iklim positif dalam sebuah tim (Olukayode \& Ehigie, 2005). Pengaruh penting kecerdasan emosional pada proses perencanaan dan kegiatan tim telah disebutkan dalam literatur sebelumnya (Robbins \& Judge, 2017). Peneliti menyarankan bahwa iklim kecerdasan emosional berharga untuk tim kerja dan komponen kerja yang sangat diperlukan (Olukayode \& Ehigie, 2005). Tim kerja yang dikelilingi oleh iklim kecerdasan emosional yang tinggi cenderung memiliki kemauan yang kuat untuk terus bekerja sama untuk perencanaan tim mereka. Penelitian sebelumnya tentang iklim kecerdasan emosional menunjukkan bahwa tim dengan iklim kecerdasan emosional yang kurang terdefinisi dengan baik mempengaruhi konflik hubungan dan peningkatan intensitas konflik (Ayoko et al., 2008), menyebabkan perencanaan tim yang lemah. Iklim kecerdasan emosional secara positif mempengaruhi berbagai perencanaan tim kerja, termasuk keterpaduan tim dan proses interaksi tim (Olukayode \& 
Ehigie, 2005). Singkatnya, iklim kecerdasan emosional memberi tim kesempatan untuk mengurangi konflik, dan meningkatkan kohesi organisasi dengan membuat skenario yang saling berpola bagi anggota untuk mengikuti aktivitas berdasarkan perencanaan tim, menunjukkan hubungan positif antara kecerdasan emosional dan perencanaan bersama. Dengan demikian, hipotesis diajukan seperti di bawah ini.

H3. Iklim kecerdasan emosional berpengaruh positif dan signifikan terhadap perencanaan tim kerja.

Iklim kecerdasan emosional dianggap sebagai lingkungan kerja di mana orang mampu memantau perasaan dan emosi mereka sendiri dan orang lain, untuk membedakan di antara mereka dan menggunakan informasi ini untuk memandu tindakan, perencanaan, dan pemikiran tim. Iklim kecerdasan emosional mempengaruhi kinerja bersama di tahap awal dan selanjutnya melalui mediator (Perlini \& Halverson, 2006). Secara khusus, iklim kecerdasan emosional membantu memecahkan masalah, yang berkontri-busi pada kinerja tim (Jordan \& Troth, 2004). Banyak penelitian telah menekankan hubungan antara iklim kecerdasan emosional dan kinerja tim (Ayoko et al., 2008), karena iklim kecerdasan emosional yang baik mewakili kemampuan untuk mengekspresikan emosi yang sesuai untuk memfasilitasi peningkatan kinerja. Iklim kecerdasan emosional yang kuat yang mendorong pemahaman emosional, regulasi, dan pemanfaatan kemungkinan akan membantu menumbuhkan pertukaran sosial yang positif, melakukan perencanaan tim yang lebih sedikit dukungan atau nasihat sosial (Ayoko et al., 2008), (DeShon \& Gillespie, 2005). Konsekuensinya, didan untuk meningkatkan kinerja tim (Cote \& kembangkan hipotesis seperti di bawah ini. Miners, 2006). Dengan kata lain, tim yang

dikelilingi oleh iklim kecerdasan emosional tingkat tinggi lebih mahir dalam mengatur emosi berbasis tim mereka dan menge-lola emosi orang lain untuk membina hubungan yang lebih positif dan produktif, akibatnya berkontribusi pada kinerja yang lebih baik. Dengan demikian, hipotesis yang diajukan seperti di bawah ini.

H4. Iklim kecerdasan emosional berpengaruh positif dan signifikan terhadap kinerja tim.

Perencanaan bersama adalah proses pengaturan mandiri yang penting (Asbari, Novitasari, et al., 2020; Asbari, Purba, et al., 2021b; Asbari, Purwanto, et al., 2020; Johan et al., 2021; Jumiran et al., 2020; Novitasari et al., 2020; Novitasari \& Asbari, 2020a, 2020b; Purwanto, Asbari, et al., 2020; Purwanto, Tukiran, et al., 2020) yang secara positif mempengaruhi hasil kinerja tim. DeShon \& Gillespie (2005) mengusulkan "rencana aksi tim" sebagai alat untuk mencapai penguasaan dan orientasi tujuan yang membuktikan kinerja. Dengan demikian menandakan hubungan perencanaan kinerja. Studi sebelumnya secara empiris menunjukkan hubungan langsung antara perencanaan tim kerja dan kinerja tim. Peneliti lain misalnya, Evain et al. (2019) menemukan pengaruh positif dari perencanaan tim kerja terhadap kinerja kelompok. Studi ini menyebutkan bahwa perencanaan tim kerja secara positif terkait dengan kinerja tim dalam tugas produksi. Dengan kata lain, tim yang terlibat dalam perencanaan tim yang lebih besar lebih mungkin untuk memperoleh kinerja yang lebih besar dibandingkan dengan tim yang 
H5. Perencanaan tim kerja berpengaruh positif dan signifikan terhadap kinerja tim.

Menurut Sekaran \& Bougie (2016) kerangka teoritis adalah fondasi yang mendasari seluruh proyek penelitian. Dari kerangka teori tersebut dapat dirumuskan hipotesis yang dapat diuji untuk mengetahui valid tidaknya teori yang dirumuskan. Kemudian selanjutnya akan diukur dengan analisis statistik yang sesuai. Mengacu pada teori dan penelitian sebelumnya, maka penulis membangun model penelitian sebagaimana pada Gambar 1.

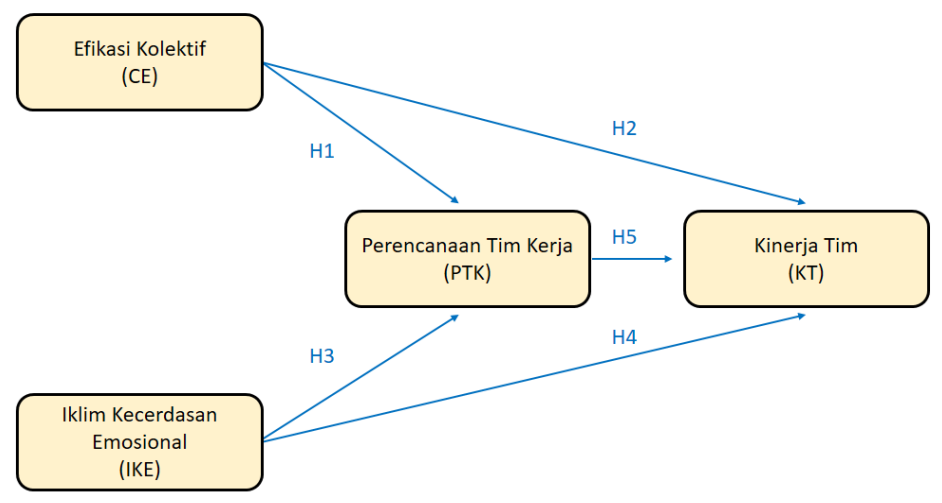

Gambar 1 Model Konseptual Penelitian

\section{METODE PENELITIAN}

Menurut Creswell \& Creswell (2017), jika tujuan dari sebuah penelitian adalah untuk mengetahui hubungan pengaruh antar variabel yang diteliti, maka pendekatan kuantitatif adalah yang terbaik. Metode penelitian kuantitatif adalah cocok dalam menguji teori dan hipotesis melalui penggunaan seperangkat alat statistik (Creswell \& Creswell, 2017). Oleh karena itu, penelitian ini menggunakan metode kuantitatif survei untuk menguji hipotesis yang dirumuskan. Oleh karena itu, diadopsi kuesioner digunakan sebagai instrumen untuk mengumpulkan data yang dibutuhkan. Sampel penelitian terdiri dari 103 anggota team penjualan sebuah industri manufaktur di Indonesia. Dengan menggunakan simple random sampling, kuesioner dikirim secara online kepada 153 populasi. 103 kuesioner dikembalikan dan valid, yang membentuk tingkat tanggapan $67.3 \%$.
Karena sifat penelitian ini yang melibatkan efek dependen antara konstruk laten dan variabel manifes, model pengukuran reflektif cocok untuk penelitian ini (Hair Jr et al., 2017). Efikasi kolektif diukur dengan menggunakan empat item (CE1-CE4) dari Mosley Jr et al. (2008). Iklim kecerdasan emosional diukur dengan menggunakan empat item (IKE1IKE4) dari Law et al. (2004). Perencanaan tim kerja diukur dengan menggunakan empat item (PTK1-PTK4) dari Mehta et al. (2009). Sedangkan untuk mengukur kinerja tim, empat item (KT1-KT4) yang diadaptasi dari Lin \& Peng (2010). Semua variabel diukur pada skala tipe Likert lima poin. Tiap item pertanyaan/pernyataan tertutup diberikan lima opsi jawaban, yaitu: sangat setuju (SS) skor 5, setuju (S) skor 4, netral/ ragu-ragu (N) skor 3 , tidak setuju (TS) skor 2, dan sangat tidak setuju (STS) skor 1 . 
Metode untuk mengolah data adalah dengan PLS yang digunakan pada penelitian ini bisa dilihat dan menggunakan software SmartPLS versi 3.0 pada Tabel 1.

sebagai toolnya. Lebih lengkap untuk daftar item

Tabel 1 Daftar Item Penelitian

\begin{tabular}{|c|c|c|}
\hline \multirow{2}{*}{\multicolumn{2}{|c|}{$\begin{array}{l}\text { Notasi } \\
\text { Efikasi kolektif (EK) }\end{array}$}} & \multirow{3}{*}{$\begin{array}{l}\text { Referensi } \\
\text { Mosley Jr et al. (2008) }\end{array}$} \\
\hline & & \\
\hline EK1 & $\begin{array}{l}\text { Tim saya percaya diri untuk saling membantu guna memenuhi tuntutan } \\
\text { kualitas kerja tim. }\end{array}$ & \\
\hline EK2 & $\begin{array}{l}\text { Tim saya percaya diri untuk saling membantu guna memperbaiki } \\
\text { kesalahan kerja tim. }\end{array}$ & \\
\hline EK3 & $\begin{array}{l}\text { Tim saya yakin dalam mengingatkan satu sama lain untuk mengikuti } \\
\text { semua aturan keselamatan. }\end{array}$ & \\
\hline EK4 & $\begin{array}{l}\text { Tim saya percaya diri dalam bekerja sama untuk menjaga efektivitas } \\
\text { kerja tim. }\end{array}$ & \\
\hline \multicolumn{2}{|r|}{ Iklim Kecerdasan Emosional (IKE) } & Law et al. (2004) \\
\hline \multicolumn{3}{|c|}{$\begin{array}{l}\text { Mengenai iklim kecerdasan emosional di tim saya, saya anggota tim merasa } \\
\text { bahwa... }\end{array}$} \\
\hline IKE1 & $\begin{array}{l}\text { Kami bisa mengendalikan amarah, sehingga kami bisa menangani } \\
\text { kesulitan secara rasional. }\end{array}$ & \\
\hline IKE2 & Kami cukup mampu mengendalikan emosi kami sendiri. & \\
\hline IKE3 & Kami selalu bisa tenang dengan cepat saat kami sangat marah. & \\
\hline IKE4 & Kami memiliki kendali yang baik atas emosi kami sendiri. & \\
\hline \multicolumn{2}{|c|}{ Perencanaan Tim Kerja (PTK) } & Mehta et al. (2009) \\
\hline PTK1 & $\begin{array}{l}\text { Tim saya memahami tujuan dari suatu masalah sebelumnya mencoba } \\
\text { menjawab. }\end{array}$ & \\
\hline PTK2 & Tim saya dengan hati-hati merencanakan tindakannya. & \\
\hline PTK3 & $\begin{array}{l}\text { Tim saya mencari tahu tujuannya dan apa yang perlu dilakukan untuk } \\
\text { mencapainya. }\end{array}$ & \\
\hline PTK4 & Tim saya mengembangkan rencana untuk solusi dari masalah. & \\
\hline \multicolumn{2}{|r|}{ Kinerja Tim (KT) } & Lin \& Peng (2010) \\
\hline KT1 & Kolaborasi tim saya mengurangi redundansi konten pekerjaan & \\
\hline KT2 & Kolaborasi tim saya meningkatkan tim efisiensi & \\
\hline KT3 & $\begin{array}{l}\text { Kolaborasi tim saya mengkoordinasikan upaya tersebut dari semua } \\
\text { orang di tim }\end{array}$ & \\
\hline KT4 & Kolaborasi tim saya memfasilitasi inovasi ide baru & \\
\hline
\end{tabular}

Table 2. Deskripsi Sampel

\begin{tabular}{llcc}
\hline & Kriteria & Jumlah & \% \\
\hline & Laki-laki & 70 & $68 \%$ \\
\hline & Wanita & 33 & $32 \%$ \\
\hline Usia (per Maret 2021) & $<30$ tahun & 26 & $25 \%$ \\
\hline & $30-40$ tahun & 48 & $47 \%$ \\
\hline Masa Kerja & $>40$ tahun & 29 & $28 \%$ \\
\hline & $<5$ tahun & 36 & $35 \%$ \\
\hline Pendidikan Terakhir & $5-10$ tahun & 51 & $50 \%$ \\
\hline & $>10$ tahun & 16 & $15 \%$ \\
\hline
\end{tabular}

Sumber: Data diolah (2021)

\section{HASIL DAN PEMBAHASAN}

Jumlah total terdapat 103 karyawan tim penjualan yang turut berpartisipasi. Terbanyak adalah pria (68\%), kemudian wanita (32\%). Mereka mempunyai kelompok usia yang berbedabeda, di bawah 30 tahun (25\%), berkisar di antara 
30-40 tahun (47\%), dan lebih dari 40 tahun (28\%). Masa kerja mereka sebagai karyawan juga cukup beragam, sebagian di antaranya di bawah 5 tahun (35\%), berkisar di antara 5-10 tahun (50\%), dan lebih dari 10 tahun (15\%). Tingkat pendidikan mayoritas diploma/sarjana (88\%) kemudian SMA/SMK (12\%),

Tahap pengujian model pengukuran meliputi pengujian validitas konvergen, validitas diskriminan. Sementara untuk menguji reliabilitas konstruk digunakan nilai cronbach's alpha dan composite reliability. Hasil analisis PLS dapat digunakan untuk menguji hipotesis penelitian jika seluruh indikator dalam model PLS telah memenuhi syarat validitas konvergen, validitas deskriminan dan uji reliabilitas.

Uji validitas konvergen dilakukan dengan melihat nilai loading factor masing-masing indikator terhadap konstruknya. Pada sebagian besar referensi, bobot faktor sebesar 0,5 atau lebih dianggap memiliki validasi yang cukup kuat untuk menjelaskan konstruk laten (Chin, 1998; Ghozali, 2014; J. F. Hair et al., 2010). Pada penelitian ini batas minimal besarnya loading factor yang diterima adalah 0,5, dengan syarat nilai AVE setiap konstruk > 0,5 (Ghozali, 2014). Setelah melalui pengolahan SmartPLS 3.0, ternyata seluruh indikator telah memiliki nilai loading factor di atas 0,5 atau dengan syarat nilai AVE di atas 0,5. Model fit atau valid dari penelitian ini bias dilihat pada Gambar 2. Jadi dengan demikian, validitas konvergen dari model penelitian ini sudah memenuhi syarat. Nilai loadings, cronbach's alpha, composite reliability dan AVE setiap konstruk selengkapnya dapat dilihat Gambar 2 dan Tabel 3.

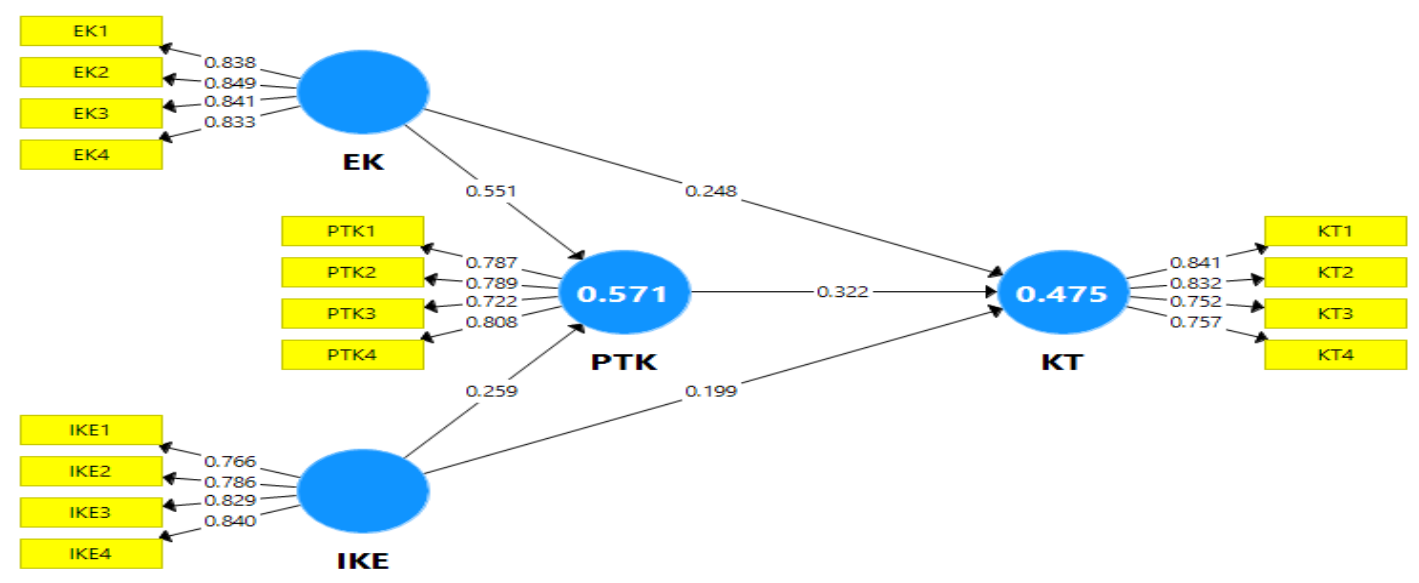

Gambar 2 Model Penelitian Valid

Sumber: Data diolah dari output SmartPLS 3.0 (2021)

Tabel 3 Items Loadings, Cronbach's Alpha, Composite Reliability, and Average Variance Extracted (AVE)

\begin{tabular}{llllll}
\hline \multicolumn{1}{c}{ Variables } & Items & Loadings & $\begin{array}{c}\text { Cronbach's } \\
\text { Alpha }\end{array}$ & $\begin{array}{c}\text { Composite } \\
\text { Reliability }\end{array}$ & AVE \\
\hline Efikasi Kolektif (EK) & EK1 & 0,838 & 0,862 & 0,906 & 0,706 \\
\cline { 2 - 6 } & EK2 & 0,849 & & & \\
\hline EK3 & 0,841 & & & \\
\hline EK4 & 0,833 & & & \\
\hline
\end{tabular}




\begin{tabular}{|c|c|c|c|c|c|}
\hline Variables & Items & Loadings & $\begin{array}{c}\text { Cronbach's } \\
\text { Alpha }\end{array}$ & $\begin{array}{l}\text { Composite } \\
\text { Reliability }\end{array}$ & $A V E$ \\
\hline \multirow[t]{3}{*}{ (IKE) } & IKE2 & 0,786 & & & \\
\hline & IKE3 & 0,829 & & & \\
\hline & IKE4 & 0,840 & & & \\
\hline Perencanaan Tim Kerja & PTK1 & 0,787 & 0,781 & 0,859 & 0,604 \\
\hline \multirow[t]{3}{*}{ (PTK) } & PTK2 & 0,789 & & & \\
\hline & PTK3 & 0,722 & & & \\
\hline & PTK4 & 0,808 & & & \\
\hline \multirow[t]{4}{*}{ Kinerja Tim (KT) } & KT1 & 0,841 & 0,808 & 0,874 & 0,635 \\
\hline & KT2 & 0,832 & & & \\
\hline & KT3 & 0,752 & & & \\
\hline & KT4 & 0,757 & & & \\
\hline
\end{tabular}

Sumber: Data diolah dari output SmartPLS 3.0 (2021)

Discriminant validity dilakukan untuk memastikan bahwa setiap konsep dari masingmasing variabel laten berbeda dengan variabel laten lainnya. Model mempunyai discriminant validity yang baik jika nilai kuadrat AVE masingmasing konstruk eksogen (nilai pada diagonal) melebihi korelasi antara konstruk tersebut dengan konstruk lainnya (nilai di bawah diagonal) (Ghozali, 2014) . Hasil pengujian discriminant validity adalah dengan menggunakan nilai kuadrat AVE, yakni dengan melihat Fornell-Larcker Criterion Value diperoleh sebagaimana ditunjukkan pada Tabel 4. Hasil uji validitas deskriminan pada tabel 3 di atas menunjukkan bahwa seluruh konstruk telah memiliki nilai akar kuadrat AVE di atas nilai korelasi dengan konstruk laten lainnya (melalui kriteria Fornell-Larcker). Demikian juga nilai cross-loading seluruh item dari suatu indikator lebih besar dari item indikator lainnya sebagaimana disebut pada Tabel 4, sehingga dapat disimpulkan bahwa model telah memenuhi validitas deskriminan (Fornell \& Larcker, 1981). Selanjutnya, evaluasi kolinearitas dilakukan untuk mengetahui apakah ada masalah kolinearitas dalam model. Untuk menemukan masalah kolinearitas, diperlukan penghitungan VIF dari setiap konstruk. Jika skor VIF lebih tinggi dari 5, maka model tersebut memiliki masalah kolinearitas (J. F. Hair et al., 2014). Sebagaimana ditunjukkan pada Tabel 5, semua skor VIF lebih kecil dari 5, artinya bahwa model ini tidak memiliki masalah kolinearitas.

Reliabilitas konstruk dapat dinilai dari nilai cronbach's alpha dan composite reliability dari masing-masing konstruk. Nilai composite reliability dan cronbach's alpha yang disarankan adalah lebih dari 0,7 (Ghozali, 2014). Hasil uji reliabilitas pada tabel 2 di atas menunjukkan bahwa seluruh konstruk telah memiliki nilai composite reliability dan cronbach's alpha lebih besar dari $0,7(>0,7)$. Kesimpulannya, seluruh konstruk telah memenuhi reliabilitas yang dipersyaratkan.

Pengujian hipotesis dalam PLS disebut juga sebagai uji inner model. Uji ini meliputi uji signifikansi pengaruh langsung dan tidak langsung serta pengukuran besarnya pengaruh variabel eksogen terhadap variabel endogen. Untuk mengetahui pengaruh efikasi kolektif, iklim kecerdasan emosional, dan perencanaan tim kerja terhadap kinerja tim, demikian juga untuk mengetahui pengaruh efikasi kolektif dan iklim kecerdasan emosional terhadap perencanaan tim 
kerja dibutuhkan uji pengaruh langsung. Uji pengaruh dilakukan dengan menggunakan uji tstatistik dalam model analisis partial least squared (PLS) dengan menggunakan bantuan software SmartPLS 3.0, Dengan teknik boothstrapping, diperoleh nilai $R$ Square dan nilai uji signifikansi sebagaimana Tabel 6 dan Tabel 7.

Tabel 4 Discriminant Validity

\begin{tabular}{lllll}
\hline \multicolumn{1}{c}{ Variabel } & EK & IKE & KT & PTK \\
\hline Efikasi Kolektif (EK) & & & & \\
\hline Iklim Kecerdasan Emosional (IKE) & 0,700 & $\mathbf{0 , 8 0 6}$ & & \\
\hline Kinerja Tim (KT) & 0,624 & 0,581 & $\mathbf{0 , 7 9 7}$ & \\
\hline Perencanaan Tim Kerja (PTK) & 0,732 & 0,645 & 0,633 & $\mathbf{0 , 7 7 7}$ \\
\hline Sumber: Data diolah dari output SmartPLS 3.0 (2021) &
\end{tabular}

Tabel 5 Collinearity Statistics (VIF)

\begin{tabular}{|c|c|c|c|}
\hline Variabel & EK IKE & KT & PTK \\
\hline Efikasi Kolektif (EK) & & 2.671 & 1.963 \\
\hline Iklim Kecerdasan Emosional (IKE) & & 2.119 & 1.963 \\
\hline \multicolumn{4}{|l|}{ Kinerja Tim (KT) } \\
\hline Perencanaan Tim Kerja (PTK) & & 2.329 & \\
\hline
\end{tabular}

Tabel 6 Nilai $R$ Square

\begin{tabular}{lll}
\hline & R Square & R Square Adjusted \\
\hline Kinerja Tim (KT) & 0,475 & 0,465 \\
\hline Perencanaan Tim Kerja (PTK) & 0,571 & 0,565 \\
\hline Sumber: Data diolah dari output SmartPLS $3.0(2021)$
\end{tabular}

Tabel 7 Hypotheses Testing

\begin{tabular}{lllllll}
\hline Hypotheses & Relationship & Beta & SE & T Statistics & P-Values & Decision \\
\hline H1 & EK -> PTK & 0,551 & 0,043 & 6.979 & 0,000 & Didukung \\
\hline H2 & EK -> KT & 0,248 & 0,034 & 2.484 & 0,013 & Didukung \\
\hline H3 & IKE -> PTK & 0,259 & 0,035 & 2.976 & 0,003 & Didukung \\
\hline H4 & IKE -> KT & 0,199 & 0,037 & 2.092 & 0,037 & Didukung \\
\hline H5 & PTK-> KT & 0,322 & 0,041 & 3.788 & 0,000 & Didukung \\
\hline
\end{tabular}

Sumber: Data diolah dari output SmartPLS 3.0 (2021)

Berdasarkan Tabel 6 di atas, nilai $R$ Square perencanaan tim kerja (PTK) sebesar 0,571 yang berarti bahwa variabel perencanaan tim kerja (PTK) mampu dijelaskan oleh variabel efikasi kolektif (EK) dan iklim kecerdasan emosional (IKE) sebesar $57,1 \%$, sedangkan sisanya sebesar $42,9 \%$ dijelaskan oleh variabel lain yang tidak dibahas dalam penelitian ini. Nilai $R$ Square kinerja tim
(KT) sebesar 0,475 yang berarti bahwa variabel kinerja tim (KT) mampu dijelaskan oleh variabel efikasi kolektif (EK), iklim kecerdasan emosional (IKE), dan perencanaan tim kerja (PTK) sebesar $47,5 \%$, sedangkan sisanya sebesar $52,5 \%$ dijelaskan oleh variabel lain yang tidak dibahas dalam penelitian ini. Sedangkan Tabel 7 menampilkan $t$ statistics dan $p$-values yang menunjukkan pe- 
ngaruh antar variabel penelitian yang telah disebutkan. Kelima jalur yang dihipotesiskan dalam penelitian ini divalidasi dan didukung pada tingkat signifikansi 0,05. Perencanaan tim kerja dipengaruhi secara positif dan signifikan oleh efikasi kolektif dan iklim kecerdasan emosional (H1 dan H3 didukung). Kinerja tim secara positif dan signifikan dipengaruhi oleh efikasi kolektif, iklim kecerdasan emosional dan perencanaan tim kerja (H2, H4, dan H5 didukung).

Penelitian ini menyajikan aplikasi dan tes yang berguna dari teori kognitif sosial yang menyatakan bahwa karakteristik tim (yaitu, efikasi kolektif) dan iklim tim (yaitu, iklim kecerdasan emosional) mendorong kinerja tim secara langsung dan tidak langsung melalui mediasi perencanaan tim kerja. Sedangkan efikasi telah dianggap sebagai penentu penting dari perilaku dan kinerja berdasarkan teori kognitif sosial, masuk akal juga bahwa, dalam kaitannya dengan perencanaan tim, iklim kecerdasan emosional (sebagaimana dikonfirmasi secara empiris oleh penelitian ini) ternyata juga signifikan sebagai prediktor untuk perencanaan tim kerja dan kinerja tim. Temuan ini masih jarang dibahas dalam literatur sebelumnya di Indonesia.

Berdasarkan literatur sebelumnya, keterkaitan yang kuat antara karakteristik masyarakat, iklim organisasi, pengaturan diri, dan kinerja yang telah ditetapkan di tingkat individu tampaknya juga ada di tingkat tim. Memperluas literatur, penelitian ini menyajikan bukti tentang bagaimana perencanaan tim kerja, memediasi efek karakteristik tim (yakni efikasi kolektif) dan iklim tim (yakni: iklim kecerdasan emosional) terhadap yang spesifik dan positif yang harus diupayakan kinerja tim. Penemuan semacam ini adalah hal oleh tim.

baru yang sangat mungkin berkembang dan memiliki potensi luar biasa untuk penelitian di masa depan. Mediasi perencanaan tim kerja belum pernah dinilai sebelumnya dalam konteks industri manufaktur di Indonesia. Efek mediasi dari perencanaan tim kerja pada hubungan tidak langsung antara iklim kecerdasan emosional dan kinerja tim menyiratkan bahwa belajar memanfaatkan kecerdasan emosional selama interaksi interpersonal memfasilitasi komunikasi yang efektif untuk perencanaan tim. Team leaders perlu membimbing anggota tim untuk mengembangkan strategi pengaturan diri untuk meningkatkan kecerdasan emosional dan menciptakan konteks kerja sama yang mendorong penggunaan strategi ini. Hasilnya, anggota tim dapat menjadi terlatih untuk menyesuaikan peran penting dari perencanaan tim kerja dalam memperkuat kinerja tim.

Melalui perencanaan tim kerja seperti itu, anggota tim dapat dikoordinasikan dengan lebih baik untuk mencapai kinerja tim yang lebih baik. Pengaruh langsung efikasi kolektif dan iklim kecerdasan emosional pada kinerja tim mengungkapkan bahwa kedua faktor tersebut memiliki kekuatan berorientasi kinerja yang kuat. Oleh karena itu, tim yang dikelilingi oleh iklim tim yang baik cenderung menunjukkan performa lebih baik ketimbang tim serupa lainnya di iklim yang tidak kondusif. Iklim kerja tim yang baik membutuhkan waktu lama untuk berkembang, jadi manajemen organisasi (dalam hal ini perusahaan manufaktur) perlu merancang saluran komunikasi yang efisien untuk anggota tim penjualannya dan mendapatkan konsensus mereka mengenai iklim kerja sama

\footnotetext{
(1)
} 
Ada tiga jalur model berbeda yang dapat memengaruhi kinerja tim. Pertama, efikasi kolektif memengaruhi kinerja tim. Kedua, iklim kecerdasan emosional memengaruhi kinerja tim. Ketiga, perencanaan tim kerja memengaruhi kinerja tim. Temuan studi ini menunjukkan bahwa perencanaan tim kerja adalah faktor paling kuat yang mendorong kinerja tim $(0,322)$ dibandingkan dengan factor iklim kecerdasan emosional $(0,199)$ dan efikasi kolektif $(0,248)$. Oleh karena itu, penting bagi manajemen untuk memberikan perhatian lebih pada aspek perencanaan kerja tim, termasuk pembagian tugas yang SMART (Specific, Measurable, Achievable, Rationale, Time Table). Kekuatan faktor-faktor ini membantu menjelaskan dengan baik masalah spesifik apa yang mungkin dihadapi anggota tim selama bergabung dalam tim penjualan.

\section{SIMPULAN}

Kesimpulannya, penelitian ini menunjukkan bahwa faktor karakteristik tim (yang diwakili oleh efikasi kolektif) dan faktor iklim tim (yang diwakili oleh iklim kecerdasan emosional) sangat memengaruhi perencanaan kerja tim dan kinerja tim. Demikian juga, perencanaan tim kerja memengaruhi secara positif dan signifikan terhadap kinerja tim. Studi ini menyakinkan bahwa teori SCT dapat diterapkan untuk memahami pembentukan kinerja tim, seperti juga menunjukkan pemahaman tentang perilaku dan kinerja individu. Studi ini juga memberikan validasi pelengkap dari teori SCT sebagai model kinerja tim dan menyarankan bahwa hal itu dapat digeneralisasikan diberbagai aktivitas tim pada organisasi lainnya.
Studi ini memiliki dua keterbatasan utama yang terkait dengan interpretasi temuan empiris. Pertama, karena penelitian ini menggunakan sampel karyawan manajerial sebuah industri manufaktur di Indonesia. Jadi, temuannya mungkin tidak secara tepat mencerminkan karakteristik dan persepsi beberapa tim di industri lain atau di negara lain atau pada budaya lain yang bisa jadi sangat berbeda sekali. Sifat terbatas dari sampel pada studi ini menyiratkan bahwa setiap generalisasi temuan dalam penelitian ini harus dilakukan dengan hati-hati. Kedua, mungkin ada faktor penentu eksogen penting lain dari kinerja tim di luar iklim tim, sebagaimana digunakan dalam dalam studi ini. Misalnya, model kepemimpinan (Goestjahjanti et al., 2020), readiness for change (Basuki et al., 2020; Novitasari, Sasono, et al., 2020a, 2020b; Zaman et al., 2020). Mengingat studi ini fokus teoritis pada SCT dan iklim tim, untuk penelitian di masa depan, penulis merekomendasikan untuk mengakomodasi lebih banyak prediktor dan membandingkan kemampuan penjelasan mereka dengan yang dinilai dalam penelitian ini. Penelitian berikutnya juga dapat mencoba untuk memperbaiki kekurangan studi ini dengan memasukkan lebih banyak variabel kontrol (misalnya, rasio perbedaan anggota dalam jenis kelamin, rasio perbedaan usia anggota, dan seterusnya), mensurvei lebih banyak anggota tim di berbagai industri dan budaya yang berbeda.

\section{DAFTAR PUSTAKA}

Asbari, M., Hidayat, D., \& Purwanto, A. (2021). Managing Employee Performance: From Leadership to Readiness for Change. International Journal of Social and Management Studies (IJOSMAS), 2(01), 74-85. https://ijosmas.org/index.php/ijosmas/article/v 
iew/12/

Asbari, M., \& Novitasari, D. (2020). The Role of Readiness for Change on Part-Timer Employee Performance: Analysis of Transformational Leadership Practice in Convection Industry. Journal of Communication Education (JOCE), 14(02). http://jurnal.ipem.ac.id/index.php/joceip/article/view/220

Asbari, M., Novitasari, D., Gazali, G., Silitonga, N., \& Pebrina, E. T. (2020). Analisis Kesiapan untuk Berubah di Masa Pandemi Covid-19: Studi Pengaruh Kepemimpinan Transformasional terhadap Kinerja Karyawan. Jurnal Perspektif, 18(2), 147-159. https://ejournal.bsi.ac.id/ejurnal/index.php/per spektif/article/view/8576

Asbari, M., \& Prasetya, A. B. (2021). Managerial Coaching: Rahasia Membangun Kinerja, Komitmen Tim dan Modal Psikologis Guru. Edumaspul - Jurnal Pendidikan, 5(1), 490-506. https://ummaspul.ejournal.id/maspuljr/article/view/1248

Asbari, M., Purba, J. T., Hariandja, E. S., \& Sudibjo, N. (2021a). From Leadership to Innovation: Managing Employee Creativity. Jurnal Manajemen Strategi Dan Aplikasi Bisnis, 4(1), 143-154. https://doi.org/https://doi.org/10,36407/jmsab. v4i1.287

Asbari, M., Purba, J. T., Hariandja, E. S., \& Sudibjo, N. (2021b). Membangun Kesiapan Berubah dan Kinerja Karyawan: Kepemimpinan Transformasional versus Transaksional. Jurnal Ilmiah Manajemen Dan Bisnis, 22(1).

Asbari, M., Purwanto, A., Fayzhall, M., Goestjahjanti, F. S., Winanti, W., Yuwono, T., Hutagalung, D. D., Basuki, S., Maesaroh, S., \& Mustofa, M. (2020). Peran Kepemimpinan Transformasional dan Organisasi Pembelajaran terhadap Kapasitas Inovasi Sekolah. EduPsyCouns: Journal of Education, Psychology and Counseling, 2(1), 122145.

Ayoko, O. B., Callan, V. J., \& Härtel, C. E. J. (2008). The influence of team emotional intelligence climate on conflict and team members' reactions to conflict. Small Group Research, 39(2), 121-149.

Bandura, A. (1977). Self-efficacy: toward a unifying theory of behavioral change. Psychological Review, 84(2), 191.

Bandura, A. (1991). Social cognitive theory of selfregulation. Organizational Behavior and Human Decision Processes, 50(2), 248-287.

Bandura, A., Rumsey, M., Walker, C., \& Harris, J. (1994). Regulative function of perceived self-efficacy. Personnel Selection and Classification, 261-271.

Basuki, S., Novitasari, D., Fahlevi, M., Nadeak, M., Fahmi, K., Pebrina, E. T., Sudiyono, R. N., \& Asbari, M. (2020). Performance Analysis of Female Employees in the Covid-19 Pandemic Period: The Effects of Readiness for Change and Effectiveness of Transformational Leadership. Solid State Technology, 63(1s), 201-217.

Chen, C.-H., Ho, Y.-H., \& Chan, L.-J. (2010). Team implicit coordination in manufactory industry: assessing the mediating role of empowering leadership and team efficacy. 2010 International Symposium on Computer, Communication, Control and Automation (3CA), 2, 459-462.

Chin, W. (1998). The Partial Least Squares Approach to Structural Equation Modeling (E. Modern Methods for Business Research, In: G. A. Marcoulides (ed.)). Lawrence Erlbaum Associates Publisher.

Choi, S. B., Kim, K., \& Kang, S. W. (2017). Effects of transformational and shared leadership styles on employees' perception of team effectiveness. Social Behavior and Personality, 45(3), 377-386. https://doi.org/10,2224/sbp.5805

Cote, S., \& Miners, C. T. H. (2006). Emotional intelligence, cognitive intelligence, and job performance. Administrative Science Quarterly, 51(1), 1-28.

Creswell, J. W., \& Creswell, J. D. (2017). Research design: Qualitative, quantitative, and mixed methods approaches. Sage publications.

Dalimunthe, H. (2018). Pengaruh Gaya Kepemimpinan dan Motivasi Kerja terhadap Kinerja Karyawan Usaha Pembungkusan Garam Konsumsi. JKBM (Jurnal Konsep Bisnis Dan Manajemen), 5(1), 5362.

DeShon, R. P., \& Gillespie, J. Z. (2005). A motivated action theory account of goal orientation. Journal of Applied Psychology, 90(6), 1096.

Evain, J., Perrot, A., Vincent, A., Cejka, J., Bauer, C., Duclos, A., Rimmelé, T., Lehot, J., \& Lilot, M. (2019). Team planning discussion and clinical performance: a prospective, randomised, controlled simulation trial. Anaesthesia, 74(4), 488-496.

Fornell, C., \& Larcker, D. F. (1981). Evaluating Structural Equation Models with Unobservable Variables and Measurement Error. Journal of Marketing Research, 18(1), 39. https://doi.org/10,2307/3151312

Gazali, Asbari, M., \& Novitasari, D. (2020). Peran Readiness for Change Mentality terhadap Kinerja Pegawai Kontrak Industri Alas Kaki. Widya Cipta: Jurnal Sekretari Dan Manajemen, 4(2), 169-182.

Ghozali, I. (2014). Structural Equation Modeling, Metode Alternatif dengan Partial Least Square (PLS) (4th ed.). Badan Penerbit Universitas Diponegoro.

Goestjahjanti, S. F., Novitasari, D., Hutagalung, D., Asbari, M., \& Supono, J. (2020). Impact of Talent Management, Authentic Leadership and Employee Engagement on Job Satisfaction: Evidence From South East Asian Industries. Journal of Critical Reviews, 7(19), 67-88.

Hair, J. F., Black, W. C., Babin, B. J., \& Anderson, R. E. 
(2010). Multivariate Data Analysis (7th ed.). Pearson Prentice Hall.

Hair, J. F., Hult, G. T., Ringle, C. M., \& Sarstedt, M. (2014). A primer partial least squaresstructural equation modeling (PLS-SEM). SAGE Publications.

Hair, Joe F, Sarstedt, M., Ringle, C. M., \& Mena, J. A. (2012). An assessment of the use of partial least squares structural equation modeling in marketing research. Journal of the Academy of Marketing Science, 40(3), 414-433.

Hair Jr, J. F., Sarstedt, M., Ringle, C. M., \& Gudergan, S. P. (2017). Advanced issues in partial least squares structural equation modeling. saGe publications.

Harmen, H. (2018). Pengaruh Talent Management dan Knowledge Management Terhadap Kinerja Karyawan PT. Perkebunan Nusantara II (Survei Pada Kantor Direksi Tanjung Morawa). Jkbm (Jurnal Konsep Bisnis Dan Manajemen), 4(2).

Joe, S.-W., \& Lin, C.-P. (2008). Learning online community citizenship behavior: A sociocognitive model. CyberPsychology \& Behavior, 11(3), 367-370,

Johan, M., Budiadnyana, G. N., Admiral, Asbari, M., \& Novitasari, D. (2021). Kepemimpinan Karismatik dalam Perspektif Karyawan UMKM: dari Motivasi Intrinsik hingga Tacit Knowledge Sharing. Edumaspul: Jurnal Pendidikan, 5(1), 598-613.

Jordan, P. J., \& Troth, A. C. (2004). Managing emotions during team problem solving: Emotional intelligence and conflict resolution. Human Performance, 17(2), 195-218.

Jumiran, Novitasari, D., Nugroho, Y. A., Sutardi, D., Sasono, I., \& Asbari, M. (2020). Pengaruh Dimensi Kepemimpinan Transformasional terhadap Kepuasan Kerja dan Komitmen Organisasional: Studi Kasus pada Dosen Perguruan Tinggi Swasta. EduPsyCouns: Journal of Education, Psychology and Counseling, 2(1), 600-621.

Kreitner, R., \& Kinicki, A. (2014). Perilaku Organisasi (9th ed.). Salemba Empat.

Law, K. S., Wong, C.-S., \& Song, L. J. (2004). The construct and criterion validity of emotional intelligence and its potential utility for management studies. Journal of Applied Psychology, 89(3), 483.

Lin, C., \& Peng, T. (2010). From organizational citizenship behaviour to team performance: The mediation of group cohesion and collective efficacy. Management and Organization Review, 6(1), 55-75.

Ma, Z., Long, L., Zhang, Y., Zhang, J., \& Lam, C. K. (2017). Why do high-performance human resource practices matter for team creativity? The mediating role of collective efficacy and knowledge sharing. Asia Pacific Journal of Management, 34(3), 565-586.

Maxwell, C., Gaudet, L., Cassir, G., Nowik, C., McLeod, N. L., Jacob, C.-É., \& Walker, M. (2019). Guideline no. 392-pregnancy and maternal obesity part 2: team planning for delivery and postpartum care. Journal of Obstetrics and Gynaecology Canada, 41(11), 1660-1675.

Mehta, A., Feild, H., Armenakis, A., \& Mehta, N. (2009). Team goal orientation and team performance: The mediating role of team planning. Journal of Management, 35(4), 1026-1046.

Mosley Jr, D. C., Boyar, S. L., Carson, C. M., \& Pearson, A. W. (2008). A production self-efficacy scale: An exploratory study. Journal of Managerial Issues, 272-285.

Novitasari, D., \& Asbari, M. (2020a). Pengaruh Kepemimpinan Transformasional terhadap Kinerja Karyawan: Peran Kesiapan untuk Berubah sebagai Mediator. Jurnal Manajemen, 10(2), 84-99. https://ejurnal.lppmunsera.org/index.php/JM/article/vie $\mathrm{w} / 2371$

Novitasari, D., \& Asbari, M. (2020b). Urgensi Kepemimpinan dan Mentalitas Siap Berubah Terhadap Kinerja Pegawai di Musim Pandemi Covid-19. Jurnal REKOMEN (Riset Ekonomi Manajemen), 4(1), 66-80,

Novitasari, D., \& Asbari, M. (2021). Leaders Coaching di Sekolah: Apa Perannya terhadap Kinerja Guru? Edumaspul: Jurnal Pendidikan, 5(1), 580-597. https://ummaspul.ejournal.id/maspuljr/article/view/1299

Novitasari, D., Asbari, M., Sutardi, D., Gazali, G., \& Silitonga, N. (2020). Pengaruh Kesiapan untuk Berubah dan Efektivitas Kepemimpinan Transformasional terhadap Kinerja Karyawan di Masa Pandemi Covid-19. Value: Jurnal Manajemen Dan Akuntansi, 18(2).

Novitasari, D., Goestjahjanti, F. S., \& Asbari, M. (2020). The Role of Readiness to Change between Transformational Leadership and Performance: Evidence from a Hospital during Covid-19 Pandemic. APMBA (Asia Pacific Management and Business Application), 9(1), 37-56. https://doi.org/10,21776/ub.apmba.2020,009.0 1.4

Novitasari, D., Sasono, I., \& Asbari, M. (2020a). WorkFamily Conflict and Worker's Performance during Covid-19 Pandemic: What is the Role of Readiness to Change Mentality? International Journal of Science and Management Studies (IJSMS), 3(4), 122-134. http://www.ijsmsjournal.org/volume3issue 4.html

Novitasari, D., Sasono, I., \& Asbari, M. (2020b). WorkFamily Conflict and Worker's Performance during Covid-19 Pandemic: What is the Role of Readiness to Change Mentality? International Journal of Science and Management Studies (IJSMS), 3(4), 122-134.

Novitasari, D., Yuwono, T., Cahyono, Y., Asbari, M., Sajudin, M., Radita, F. R., \& Asnaini, S. W. (2020). Effect of Hard Skills, Soft Skills, Organizational 
Learning and Innovation Capability on Indonesian Teachers' Performance during Covid19 Pandemic. Solid State Technology, 63(6), 2927-2952.

Olukayode, A. A., \& Ehigie, B. O. (2005). Psychological diversity and team interaction processes. Team Performance Management: An International Journal.

Otaye-Ebede, L., Shaffakat, S., \& Foster, S. (2019). A Multilevel Model Examining the Relationships Between Workplace Spirituality, Ethical Climate and Outcomes: A Social Cognitive Theory Perspective. Journal of Business Ethics, $0(0), 0$, https://doi.org/10,1007/s10551-019-04133-8

Park, W.-W., Kim, M. S., \& Gully, S. M. (2017). Effect of cohesion on the curvilinear relationship between team efficacy and performance. Small Group Research, 48(4), 455-481.

Perlini, A. H., \& Halverson, T. R. (2006). Emotional intelligence in the National Hockey League. Canadian Journal of Behavioural Science/Revue Canadienne Des Sciences Du Comportement, 38(2), 109.

Purwanto, A., Asbari, M., Santoso, P. B., Wijayanti, L. M., \& Hyun, C. C. (2020). Pengaruh Gaya Kepemimpinan Transformasional dan Tranksaksional Terhadap Kinerja Sistem Jaminan Halal HAS 23000 Pada Industri Makanan di Tangerang. BISNIS : Jurnal Bisnis Dan Manajemen Islam, 8(1), 45-56.

Purwanto, A., Mayesti Wijayanti, L., Chi Hyun, C., Asbari, M., \& Budi Santoso Post Graduate, P. (2019). ISO 38200:2018 Benefit and Timber Industries Competitiveness : Rethoric or Reality. Management and Accounting Adpertisi, 1. https://doi.org/https://doi.org/10,4536/jr.v1i1. 12

Purwanto, A., Tukiran, M., Asbari, M., Hyun, C. C., Santoso, P. B., \& Wijayanti, L. M. (2020). Model Kepemimpinan di Lembaga Pendidikan: A Schematic Literature Review. Journal of
Engineering and Management Science Research (JIEMAR), 1(2), 255-266.

Robbins, S. P., \& Judge, T. A. (2017). Organizational behavior, Edition 17, Global edition. Boston: Pearson.

Roscoe, J. T. (1975). Fundamental research statistics for the behavioral sciences [by] John T. Roscoe.

Sarstedt, M., Ringle, C. M., Smith, D., Reams, R., \& Hair Jr, J. F. (2014). Partial least squares structural equation modeling (PLS-SEM): A useful tool for family business researchers. Journal of Family Business Strategy, 5(1), 105-115.

Sekaran, U., \& Bougie, R. (2016). Research methods for business: A skill building approach. John Wiley \& Sons.

Singgih, E., Iskandar, J., Goestjahjanti, F. S., Fahlevi, M., Nadeak, M., Fahmi, K., Anwar, R., Asbari, M., \& Purwanto, A. (2020). The Role of Job Satisfaction in the Relationship between Transformational Leadership, Knowledge Management, Work Environment and Performance. Solid State Technology, 63(2s), 293-314. http://www.solidstatetechnology.us/index.php/J SST/article/view/1556

Yaakobi, E., \& Weisberg, J. (2020). Organizational citizenship behavior predicts quality, creativity, and efficiency performance: The roles of occupational and collective efficacies. Frontiers in Psychology, 11, 758.

Zaman, M. N., Novitasari, D., Goestjahjanti, F. S., Fahlevi, M., Nadeak, M., Fahmi, K., Setiawan, T., \& Asbari, M. (2020). Effect of Readiness to Change and Effectiveness of Transformational Leadership on Workers ' Performance during Covid-19 Pandemic. Solid State Technology, 63(1s), 185200, http://www.solidstatetechnology.us/index.php/ JSST/article/view/708 